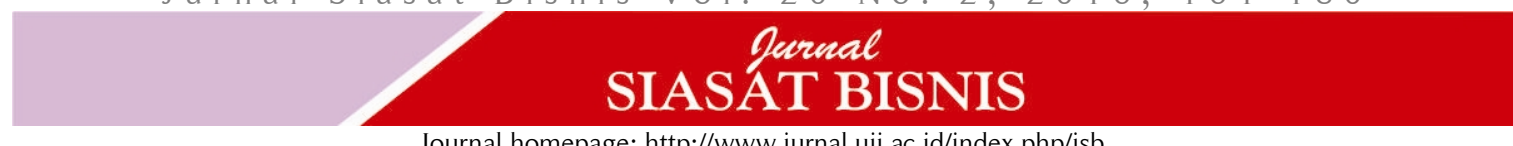

Journal homepage: http://www.jurnal.uii.ac.id/index.php/jsb

\title{
Analisis Tingkat Implementasi Good Corporate Governance Pada Usaha Kecil dan Menengah
}

\author{
Jaswadi
}

\author{
Politeknik Negeri Malang, Malang, Indonesia \\ e-mail: jaswadi@polinema.ac.id
}

\begin{abstract}
Small and Medium Enterprises (SMES) play an important role in terms of contributing the national economy in Indonesia. Government has specified a Long-term Development Program (2005-2025) which one of the strategic programs is to strengthen SMEs position by improving access for financing, production, marketing and management. Despite the aforementioned, prior research shows that the sustainability issues of these ventures are amongst the serious problem, which is believed to be caused by an economic factor. One of economic factors which have been perceived by previous research as a critical problem is the lack of governance mechanism. The governance issue rests with the management of an SME entities. The main objective of the study is to investigate the implementation of governance in SMEs in Indonesia, specifically in the Greater Malang Region of East Java Province. Questioners were distributed to 150 owners and/or managers of SMEs and administered from 49 respondents. Based on the finding, it is obvious that implementation of corporate governance mechanism was quite limited. The implication of this article explores the possibility of suitable dimensions for better SMEs governance in Indonesia.
\end{abstract}

Keywords: corporate governance, Indonesia, small and medium enterprises

\begin{abstract}
Abstrak
Perusahaan Kecil dan Menengah (UKM) Indonesia mempunyai peran sangat penting dalam perekonomian nasional. Pemerintah telah menetapkan Rencana Pengembangan Jangka Panjang (2005-2025) dengan salah satu program stratejiknya berupa penguatan posisi UKM dengan memperperbaiki akses terhadap jasa keuangan, produksi, pemasaran dan manajemen. Selain hal tersebut, penelitian yang ada menunjukkan bahwa permasalahan sustainability UKM merupakan masalah serius, yang diyakini karena faktor ekonomi. Salah satu faktor ekonomi adalah persoalan kritis yakni lemahnya mekanisme tata kelola (governance) perusahaan. Permasalahan governance umumnya ada pada manajemen/pengelola organisasi UKM. Tujuan utama penelitian ini adalah untuk melakukan investigasi dalam mengidentifikasi sebuah dasar pengetahuan (knowledge base) atas implementasi good corporate governance pada sektor UKM, serta mengidentifikasi aspek pengaturan yang perlu dimodifikasi atas implementasi good corporate governance pada sektor UKM. Kuisioner penelitian dikirimkan kepada 150 calon responden (pemilik dan atau manajer) dan dianalisis dari 49 responden yang berpartisipasi. Survei pada penelitian ini menemukan bahwa implementasi mekanisme good corporate governance pada UKM di wilayah Malang Raya masih sangat terbatas. Implikasi dari penelitiaan ini adalah perlunya melakukan eksplorasi lebih lanjut terhadap dimensi governance yang lebih cocok untuk mendukung terciptanya mekanisme good corporate governance pada UKM.
\end{abstract}

Kata kunci: corporate governance, Indonesia, Usaha Kecil dan Menengah (UKM)

JEL: G30, G38, M10, M13

DOI: $10.20885 /$ jsb.vol20.iss2.art5

\section{Introduction}

Usaha mikro, kecil dan menengah (UMKM) merupakan bagian sangat penting dalam perekonomian Indonesia. Dari keseluruhan unit usaha di Indonesia, 99,99\% total unit usaha merupakan UMKM, dan mempekerjakan hampir sejumlah 97,24\% dari seluruh angkatan kerja (Kemenkop UKM, 2012). Sektor UMKM telah melakukan ekspor sebesar 16\% dari total ekspor non migas, serta menyumbang $57,94 \%$ dari total pendapatan domestik bruto (PDB) Indonesia atas dasar harga berlaku (Kemenkop 
UKM, 2012). Fakta ini membuktikan bahwa UKM sangatlah penting dalam roda perekonomian nasional.

Undang-undang 20 tahun 2008 tentang UMKM mendefinisikan bahwa batasan maksimum aset dari sebuah UKM adalah sebesar Rp10 milyar (tidak termasuk tanah dan bangunan) serta pendapatan sejumlah Rp50 milyar/tahun. Hal ini memberikan dukungan fakta bahwa mayoritas entitas usaha di Indonesia masuk dalam katergori mikro sampai jenis usaha menengah tersebut. Upaya meningkatkan kemampuan dan kemandirian manajerial menjadi isu sangat penting. Dalam RPJM II 2010 - 2014, secara eksplisit dijelaskan bahwa sangat perlu untuk 'meningkatkan dan memajukan usaha kecil menengah (UKM) dengan menambah akses terhadap modal' dan 'melaksanakan kebijakan pemihakan untuk memberikan ruang usaha bagi pengusaha kecil dan menengah'. Kemandirian sektor UKM harus mendapat prioritas untuk menjamin kekompetitifan dan keberlanjutannya. Salah satu upaya pengembangan dukungan untuk meningkatkan peran UKM dalam perekonomian, seperti pedoman good corporate governance, mendesak dilaksanakan.

Ketika diskusi tentang corporate governance telah banyak dilakukan pada perusahaan besar yang tercatat di bursa efek dengan konteks Negara maju (OECD, 2006), tantangan bagaimana hal ini diterapkan pada perusahaan skala kecil dan menengah perlu mendapat perhatian, khususnya pada negara-negara dimana pasar modal belum terlalu dominan. Penelitian-penelitian pada topik corporate governance dan UKM masih diperlukan, walaupun telah ada kajian dan bahkan OECD juga telah menerbitkan buku "corporate governance of non-listed companies in emerging markets". Pemangku kepentingan dari sektor UKM, seperti terlupakan (Clarke, 2007). Sebagai contoh kasus di Negara sedang berkembang, seperti Indonesia dengan 99,99\% dari total unit usaha merupakan UMKM, sangat memerlukan sudut pandang bagaimana mekanisme good corporate governance dapat diterapkan pada skala usaha ini, dan memberikan manfaat kepada pelaku UKM dan memberi multiplier effect terhadap perekonomian.

Fakta lain dari pasar modal Indonesia menjelaskan bahwa gambaran signifikan potensi UKM ternyata berbanding terbalik dengan fakta bahwa hanya 9 (sembilan) perusahaan yang go public sejak 2004 sampai 2011 (BAPEPAM-LK, 2011). Sementara penelusuran lebih lanjut, hanya ada 14 (empat belas) emiten yeng tercatat sahamnya sampai akhir tahun buku 2014 (IDX Faxbook, 2014). Dalam laporannya BAPEAM-LK menjelaskan bahwa para pengelola atau pemilik perusahaan belum mengedepankan aspek keterbukaan informasi kepada publik. Penjelasan lebih lanjut menjelaskan bahwa sebagain besar perusahaan UKM masih menjalankan usahanya secara konvensional dan belum mengimplementasikan prinsip-prinsip tata kelola perusahaan yang baik (good corporate governance). Namun demikian, pedoman dan regulasi tentang implementasi good corporate governance lebih tepat pada perusaahan skala besar, dimana kecenderungan menjadi sebuah beban yang terlalu berat pada perusahaan skala UKM. Kondisi ini mendorong pemerintah, pengusaha UKM, dan juga akademisi untuk mengidentifikasi permasalahan dan mencarikan solusi bagaimana implementasi good corporate governance tersebut pada sektor UKM yang potensial tersebut.

Implementasi good corporate governance bermanfaat dalam rangka membantu UKM untuk memperbaiki prospek mereka dalam rangka mendapatkan alternatif pendanaan baik dari investor dan institusi keuangan. Prinsip usaha yang diterapkan UKM, secara praktiknya dapat dikaitkan dengan konsep governance yang diterapkan pada jenis usaha besar saat ini. Selain merapatkan prinsip TARIF (KNKG, 2006), impelementasi prinsip governance pada UKM berdampak langsung terhadap pelaksanaan pencatatan dan akuntansi yang proper serta pengungkapan informasi yang dapat meningkatkan kepercayaan para investor pada perusahaan skalam UKM tersebut (Abor and Adjasi, 2007a; Dube, Dube and Mishra, 2011).

Dalam rangka memberikan rerangka atas implementasi good corporate governance di sektor UKM, saran-saran praktis berupa panduan bagaimana melakukan implementasi atas good corporate governance pada UKM menjadi sangat diperlukan. Artikel ini mengangkat permasalahan penelitian yakni faktor-faktor apakah yang menjadi indikator dalam implementasi good corporate governance pada sektor UKM. Tujuan penelitiannya adalah untuk melakukan investigasi dalam 
mengidentifikasi sebuah dasar pengetahuan (knowledge base) atas implementasi good corporate governance pada sektor UKM, serta mengidentifikasi aspek pengaturan yang perlu dimodifikasi atas implementasi good corporate governance pada sektor UKM.

\section{Kajian Pustaka}

\section{Implementasi GCG pada Perusahaan Besar dan UKM}

Good corporate governance didefinisikan sebagai 'sebuah sistem dimana perusahaan diarahkan dan dikendalikan' (Cadbury, 1999: para 2.5). Dalam penelitian ini, corporate governance mengacu pada sebuah sistem yang mengatur dan mengawasi jalannya perusahaan dan menyeimbangkan semua kepentingan pemangku kepentingan dalam hal menjamin perilaku organisasi yang bertanggungjawab dan mencapai efisiensi dan profitabiltias perusahaan (DuPlessis, James \& Mirko, 2005).

Pentingnya good corporate governance ditandai dengan bangkrutnya beberapa perusahaan konglomerasi seperti kasus Barings Bank tahun 1995, Enron tahun 2001 dan Royald Ahold tahun 2003. Ketiga kasus ini sebagai salah satu contoh perusahaan besar di United Kingdoms (UK), United States (US) dan Eropa dan mengilustrasikan kelemahan-kelemahan dalam mengatur sebuah perusahaan. Kasus Baring Bank menjadi teladan tentang kelemahan sebuah sistem pengendalian internal (SPI) dan kepercayaan yang berlebihan terhadap salah satu karyawan inti tanda supervisi dan pemahaman atas kebijakan investasinya. Enron memberikan contoh yang sangat jelas tentang kebutuhan etika bisnis dan integritas dari para direktur perusahaan, dan peran penting dari auditor independen dalam menjalankan tugasnya. Terakhir, Royald Ahold menggambarkan kejadian jika mekanisme pengawasan investor dikelabuhi, dimana CEO menjadi orang satu-satunya yang dominan dalam struktur organisasi.

Sebuah mekanisme corporate governance 'berkenaan dengan cara-cara dimana para penyedia modal melakukan upaya untuk mendapatkan sebuah return atas investasi mereka' (Shleifer \& Vishhny, 1997: 737). Permasalahan muncul jika para penyedia modal (pemilik) mempekerjakan orang (tim dalam top management) untuk menjalankan operasi perusahaan secara bertanggungjawab. Seperti dalam sub bagian sebelumnya, masalah akan cenderung terjadi jika kepentingan dari pihak-pihak tersebut berbeda dan informasi untuk pengambilan keputusan menjadi tidak simetris (Barle \& Means, 1932; Jensen \& Meckling, 1976). Dalam rangka menyamakan persepsi dan mengurangi informasi yang tidak simetris, banyak kajian menjelaskan pentingnya 'board of directors' untuk menjembatani hubungan antara pemilik dan manajer.

Penelitian sebelumnya mengklasifikasikan 2 (dua) model corporate governance yakni model Eropa Kontinental dan Anglo-Amerika (DuPlessis, James \& Mirko, 2005; Enriques \& Volpin, 2007; Wibowo, 2008). Model US sebagai contoh model Anglo-Amerika dengan shareholders approach, dan model Jerman merupakan contoh model Eropa Kontinental, yang menggunakan pendekatan stakeholders approach.

Dalam perspektif besaran perusahaan (company size), penelitian terdahulu menjelaskan adanya kecenderungan perusahaan besar akan lebih terbuka dalam informasi dan menyajikan kualitas pelaporan yang lebih baik dibanding perusahaan berukuran lebih kecil (Albrecth \& Richardson, 1990). Oleh karena itu, upaya mengkiritisi efektivitas mekanisme governance cenderung menggunakan obyek perusahaan besar dan tercatat di bursa efek. Lebih lanjut, Rezaee and Riley (2010) menjelaskan elemen dari corporate governance meliputi: board of directors (model one/two tier board systems), komite audit, tim manajemen puncak, auditor internal, auditor eksternal dan lembaga pengawas pemerintah. Struktur ini diperlukan dalam rangka memastikan manajemen dimonitor dan berperilaku akuntabel dalam membelanjakan sumber daya secara efisien dan efektif.

Struktur dalam gambar 1 umumnya diterapkan pada perusahaan besar dan tercatat di bursa efek. Lebih lanjut, selain OECD (2006) yang telah mempublikasi mekanisme corporate governance pada perusahaan non-listed di Negara sedang berkembang, beberapa publikasi telah membahas mekanisme serupa pada usaha skala kecil dan menengah (UKM) semisal: Abor and Adjasi (2007) 
sebuah studi di Ghana dan Dube, Dube dan Mishra (2011) di India, Htay dan Salman (2013) di Malaysia.

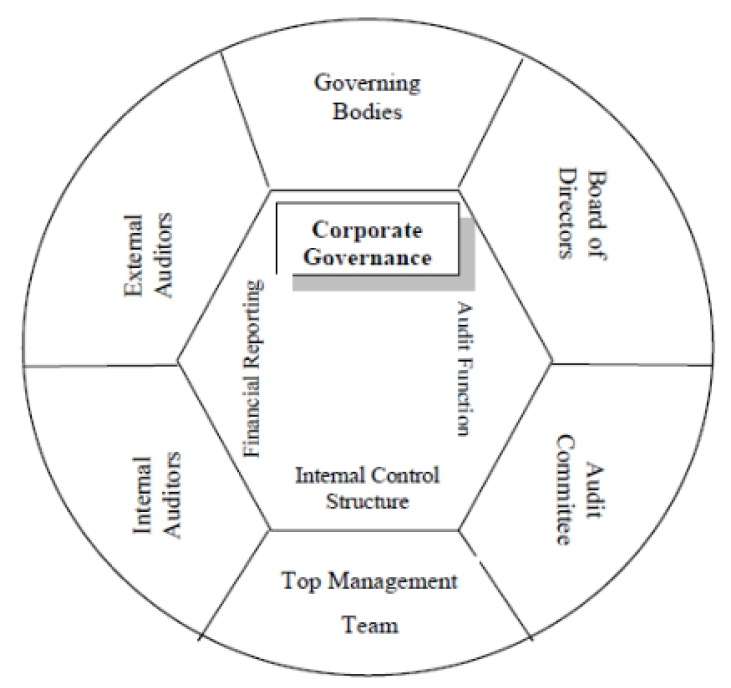

Gambar 1. Corporate governance dan Fungsi Terkait Sumber: Diadopsi dari Rezaee and Riley (2010, p.123)

\section{Mengapa UKM Memerlukan Implementasi GCG}

Berkaitan dengan elemen good corporate governance, tidak ada 'one size to fit all'. Dalam rangka untuk mengakomodasi nilai dan kebutuhan lokal, Negara tertentu perlu menciptakan standar lokal mereka sendiri. Beberapa ahli tidak sependapat atas dibuatnya standar global untuk good governance. Iu dan Batten (2001) menawarkan sebuah pandangan, walaupun cara bisnis dan perdagangan antar Negara sama belum tentu berarti sama dalam budaya, perbedaan budaya tetap ada. Asian Development Bank (ADB, 1999; 2000) dan World Bank (1999) menyatakan bahwa tidak ada standar tunggal atas model corporate governance yang dapat diterapkan memecahkan masalah perusahaan pada kondisi yang berbeda-beda. Dalam pernyataan khususnya, ADB (2000a; 6) menyatakan bahwa "(e)ach country should formulate its own reform plan and implement measures that suit its specific condition". Oleh karena itu, setiap Negara dapat memformulasikan sendiri dan mengunakan ukuran yang sesuai dengan kondisi khusus yang ada, termasuk memformulasi model GCG yang cocok dengan kebutuhan UKM.

Ada 2 (dua) pandangan yang berimbang dalam menentukan perlu atau tidaknya pedoman khusus GCG untuk UKM (Abor dan Adjasi, 2007). Pertama, pandangan yang menjelaskan tidak perlunya GCG pada UKM karena masalah keagenan tidak ada pada skala UKM, hal ini karena skala usaha ini hanya terdiri dari pemilik dan beberapa karyawarn sehingga mekanisme owner-manager mentiadakan masalah keagenan yang biasanya ada pada perusahaan besar. Sementara kedua, ada perhatian global atas penerapan GCG pada UKM (OECD, 2006). Panduan untuk perusahaan terbuka seharusnya dapat juga digunakan oleh UKM, bukan pada aspek kekomplekannya, tetapi pada penerapan prinsip-prinsip untuk menerapkan sebuah sistem tata kelola yang efektif. Manfaat dari implemetasi good corporate governance pada UKM adalah mereka para wirausahawan yang tumbuh dari UKM dan menjadi usaha besar (UB). UKM membutuhkan tambahan sumber daya (seperti: keuangan, aset dan teknologi) untuk tumbuh, penerapan prinsip-prinsip GCG akan meningkatkan status bankable dan investable perusahaan tersebut. Hal ini juga sejalan dengan adanya upaya pasar modal memberi peluang UKM untuk go public (BAPEPAM-LK, 2011) pada kelompok papan pengembangan (development board), sebelum layak masuk dalam papan utama. 
Lebih lanjut praktik di India, Dube, Dube \& Mishra (2011) menjelaskan bahwa praktik sukarela (voluntarily practices) good corporate governance membantu UKM dalam rangka memperbaiki prospek mereka untuk mendapatkan alternatif pendanaan baik dari investor maupun institusi keuangan. Hal tersebut merupakan dampak langsung dari pelaksanaan proper bookkeeping and accounting dan pengungkapan informasi yang meningkatkan kepercayaan para investor pada UKM tersebut. UKM akan lebih berkomitmen pada efisiensi dengan hadirnya 'pihak pengawas dan penasehat' luar. Penerapan prinsip-prinsip good corporate governace akan mengurangi masalah berkaitan dengan informasi yang tidak simetris dan membuat UKM lebih bebas risiko dalam sudut pandang investasi (Mahmood, 2008; Shanthy \& Elsa, 2009).

Pedoman GCG pada UKM bahkan telah dikeluarkan oleh beberapa otoritas pemerintahan dalam rangka mendukung pertumbuhan UKM, seperti yang dilakukan oleh lembagai DUBAI SME (2011) dan Hong Kong Institute of Directors (2009). DUBAI SME, sebuah lembaga yang mengurusi UKM dan didukung oleh International Finance Corporation (IFC) pada tahun 2011 mempublikasikan sebuah pedoman tertulis bagaimana good corporate governance dilakukan pada UKM. Terdapat 6 (enam) seksi yang terbagi dalam 9 (sembilan) pilar yang perlu disiapkan oleh UKM, diantaranya:

a. Kebijakan dan prosedur corporate governance,

b. Transparansi dan hubungan dengan pemegang saham/pemilik,

c. Board of Directors (atau dalam kontek Indonesia, Dewan Komisaris dan Direksi),

d. Lingkungan pengendalian,

e. Hubungan dengan pemangku kepentingan, dan

f. Family governance.

Pedoman ini memberikan penjelasan yang terinci atas implementasi GCG pada UKM. Survei tersebut telah berhasil memformulasikan sebuah pedoman bagaimana mekanisme good corporate governance dilakukan pada sektor UKM di Dubai. Perbedaan mendasar terletak pada bagaimana modifikasi struktur dilakukan pada perusahaan yang lebih kecil, semisal pada perusahaan perseorangan serta entitas bisnis belum berbadan hukum. Selain itu, family governance menjadi salah satu isu yang harus diungkapkan untuk mendorong penerapan prinsip kewajaran (fairness) pada operasi UKM yang sebagian besar dimiliki oleh keluarga.

Pedoman yang dikeluarkan oleh DUBAI SME merupakan pedoman tertulis yang dapat dijadikan acukan oleh berbagai negara, termasuk Indonesia, untuk mengembangkan pola adaptasi. Clark (2007) menjelaskan bahwa dalam pengembangan code of corporate governance, UKM merupakan stakeholder yang terlupakan baik oleh regulator, pasar modal maupun akademisi. Sehingga data hasil survei DUBAI SME (2011) dapat dijadikan sebagai knowledge base yang sangat berharga untuk dikembangkan di berbagai negara lainnya, termasuk di Indonesia. Selanjutnya Otoritas Hong Kong pada tahun 2009 mempublikasi pedoman serupa yang mengelompokkan 5 (lima) kategori UKM mereka mulai dari category 1 (small entities woned by single individual) sampai dengan category 5 (SMEs listed on the Stock Exchange of the Hong Kong). Hong Kong memberikan perlakukan khusus UKMnya yang telah listing di Bursa Efek dan tidak 'dipaksa' mematuhi aturan GCG yang komplek serta lebih cocok untuk entitas kategori usaha besar. Berbagai kajian pustaka dari Negara berkembang mendukung adanya pedoman khusus atas aspek corporate governance pada UKM, tidak disamakan dengan usaha besar (Htay \& Salam, 2013; Dube, Dube \& Mishra, 2011; Abor \&Adjasi, 2007; Mahmood, 2008).

\section{GCG pada UKM di Indonesia}

Di Indonesia, implementasi GCG secara umum mengacu pada Pedoman GCG yang dikeluarkan oleh Komite National Kebijakan Governance (KNKG) tahun 2006 dan pedoman sektoral lainnya. Pedoman ini bukan merupakan aturan legislasi formal yang mempunyai kekuatan hukum tetap dalam pelaksanaanya, namun demikian, ini menjadi pedoman penting bagi perusahaan dalam 
memastikan keberlanjutan perusahaan dalam koridor etika bisnis. Beberapa hal penting yang disajikan dalam pendahuluan tujuan dari pedoman GCG ini antara lain:

a. Untuk mencapai pertumbuhan berkelanjutan melalui sistem manajemen berbasis prinsip transparansi, akuntabilitas, responsibilitas, independensi, dan kewajaran.

b. Untuk memperkuat fungsi dan independensi masing-masing struktur perusahaan, khususnya, dewan komisaris, direksi dan rapat umum pemegang saham.

c. Untuk mendorong pemegang saham, anggota dewan komisaris dan direksi untuk mengambil keputusan berdasarkan nilai moral dan kepatuhan terhadap hukum dan aturan.

d. Untuk mendorong kesadaran atas tanggungjawab sosial perusahaan.

e. Untuk meningkatkan nilai perusahaan untuk pemegang saham dan juga mempertimbangkan pemangku kepentingan lainnya.

f. Untuk meningkatkan daya saing perusahaan.

Dari 6 (enam) tujuan tersebut, KNKG (2006) telah menjelaskan dalam 8(delapan) bagian untuk memberikan pedoman teknis implementasi good corporate governance, utamanya pada entitas Perseroan Terbatas (PT). Diskusi lebih lanjut memunculkan bagaimana model yang cocok (fit) dengan entitas lain semisal persekutuan komanditair (CV), persekutuan lainya dan bahkan usaha perseorangan.

Mencermati litaratur yang ada di Indonesia, telah banyak penelitian yang membahasa objek UKM (Tambunan, 2005; 2008), namun masih sedikit studi yang mengkaji pelaksanaan good corporate governance di UKM (Maskur, 2012; Purwanto \& Mustamu, 2013). Maskur (2012) melakukan analisis pada 54 perusahaan UMKM binaan unit PKBL PT. Taspen. Tbk, menggunakan analisis elemen TARIF pada masing-masing responden. Penelitian tersebut menyimpulkan GCG telah dilaksanakan dengan baik, namun masih buruk pada aspek transparansi dan akuntabilitas. Sementara Purwanto dan Mustamu (2013) melakukan wawancara dan pengamatan atas implementasi elemen TARIF pada sebuah perusahaan keluarga dibidang manufaktur kayu di Surabaya, dimana implementasi mekanisme GCG dikategorikan baik. Dalam analisis lebih lanjut, Maskur (2012) mendapatkan sampel pada kelompok usaha mikro dan kecil (tidak ada kategori usaha menengah), sementara pada Purwanto dan Mustamu (2013) belum menjelaskan perusahaan keluarga pada skala UKM atau usaha besar. Upaya lebih lanjut untuk mengeksplorasi mekanisme governance pada usaha kecil dan menengah masih diperlukan.

\section{Metode Penelitian}

\section{Desain Penelitian}

Penelitian ini akan mengadopsi jenis penelitian explanatory dengan survey design (Creswell, 2009) untuk melakukan penarikan kesimpulan atas opini dari dari sampel partisipan UKM dari populasi UKM. Objek penelitian ini adalah pemilik-pengelola atau pengelola (manajer) dari usaha yang masuk dalam kategori usaha kecil dan menengah (UU 20 Tahun 2008) yang berlokasi di 3 (tiga) dearah di Jawa Timur - Kabupaten Malang, Kota Malang dan Kota Batu. Tiga Daerah ini dipilih karena merupakan salah satu kawasan tumbuh cepat mulai Industri, Pariwisata, Pertanian, dan Pendidikan Jawa Timur.

\section{Populasi dan Sample Penelitian}

Populasi penelitian ini adalah sejumlah total UKM Unggulan Jawa Timur yang terdiri dari 547 UKM Perintis Ekspor dan 6.247 UKM Pelaku Ekspor (Dinas Koperasi \& UMKM Jawa Timur, 2012). Metode pengambilan sampel adalah purposive sampling dengan menggunakan kriteria beroperasi dalam 3 (tiga) wilayah daerah penelitian tersebut. Responden dari penelitian ini ditujukan kepada pemilik atau manajer dari responden UKM. 


\section{Metode Pengumpulan Data}

Penelitian ini mengembangan instrumen penelitian berupa kuisioner untuk mengumpulkan data melalui survey. Instrumen penelitiaan dirancang berdasarkan kajian pustaka dan dikembangkan dari pilar good corporate governance pada UKM (DUBAI SME, 2011). Pedoman dari lembaga DUBAI SMEs ini sejauh ini menjelaskan elemen good corporate goverance paling komprehensif untuk UKM dibandingkan dengan KNKG (2006) yang lebih fokus pada entitas Perseroan Terbatas, maupun pedoman lain dari otoritas Hong Kong SMEs (2009) dan Norm for SME Governance dari India (Dube, Dube dan Mishra, 2011).

Instrumen berupa kuisioner yang berisi sejumlah pertanyaan dan pernyataan untuk dijawab dan disetujui oleh para responden penelitian. Secara umum kuisioner ini digunakan untuk memperoleh data kuantitatif tentang implementasi mekanisme good corporate governance di UKM dengan memberikan persepsi atas pernyataan-pernyataan persetujuan dengan skala likert dari tingkat tidak setuju (skor=1) sampai dengan sangat setuju (skor=5) seperti telah dilakukan oleh Siwangaza et al. (2014) dan pertanyaan-pertanyaan dengan jumlah aktivitas dengan skala interval rendah (skor=1) sampai dengan tinggi (skor=4). Instrumen divalidasi oleh ahli manajemen ( 2 orang) dan pelaku UKM (2 responden). Secara analisis kuantitatif, Hair et al. (1998) menjelaskan bahwa instrumen dikategorikan valid pada saat Cronbach's alpha tidak kurang dari 0,6 sampai dengan 0,70.

Penelitian ini mempertimbangkan untuk lebih konservatif dalam melakukan analisis kuantitatif pada draft instrumen penelitian, dimana butir-butir pertanyaan penelitian dengan Cronbach's alpha dibawah 0,7 akan dikaji ulang. Berdasarkan output SPSS dalam tabel 1, terdapat 3 kelompok butir pertanyaan yang memiliki Alpha kurang dari 0,7 yaitu Kinerja Dewan/Penasehat (pilar 5), Pengendalian Internal (Pilar 7) dan Tata Kelola Keluarga (pilar 9).

Tabel 1. Hasil Analisis Reliabilitas

\begin{tabular}{clccc}
\hline \multicolumn{5}{c}{ Mekanisme corporate governace } \\
\hline \multirow{2}{*}{ No } & \multicolumn{1}{c}{ Construct } & Item Pernyataan & $\begin{array}{c}\text { Pertanyaan } \\
\text { Tambahan }\end{array}$ & Alpha \\
\hline 1 & Rerangka formal & 2 & 2 & 0,84 \\
2 & Pergantian pimpinan & 2 & 1 & 0,76 \\
3 & Informasi dan komunikasi & 2 & 2 & 0,71 \\
4 & Dewan komisaris/penasehat & 4 & 0 & 0,83 \\
5 & Kinerja dewan/penasehat & 4 & 4 & 0,65 \\
6 & Audit eksternal & 2 & 0 & 0,76 \\
7 & Pengendalian internal & 5 & 2 & 0,54 \\
8 & Pemangku kepentingan & 2 & 2 & 0,71 \\
9 & Family governance & 2 & 2 & 0,61 \\
\hline
\end{tabular}

Sumber: data pilot study, 2014.

Kecilnya alpha dimungkinkan adanya kesamaan substansi pertanyaan, sehingga beberapa butir pertanyaan sebenarnya refleksi dari pertanyaan lainnya. 'A poorly worded item' dapat menghasilkan alpha yang rendah (Hullan, 1999: hal 198 dalam Wibowo, 2008). Sehingga, instrumen dikaji ulang pada 3 constructs tersebut untuk dapat menjadi instrumen yang andal pada saat digunakan pada survey sebenarnya. Perbaikan dilakukan dengan mengkaji ulang butir-butir pertanyaan yang tidak dimengerti oleh pelaku UKM.

\section{Hasil Penelitian dan Pembahasan}

\section{Informasi Umum Responden}

Penelitian dilakukan dengan mengirim kuisioner kepada 150 UKM di 3 (tiga) daerah di wilayah Jawa Timur, meliputi wilayah Kota Malang, Kabupaten Malang dan Kota Batu. Calon responden 
dipilih dengan metode non-probability purposive sampling dari daftar perusahaan UKM sebanyak 150 UKM. Dari 150 calon responden, sebanyak 49 responden yang berpartisipasi dengan mengembalikan instrumen penelitian melalui Pos dan dijemput oleh enumerator penelitian. Berikut informasi umum yang diperoleh dari responden.

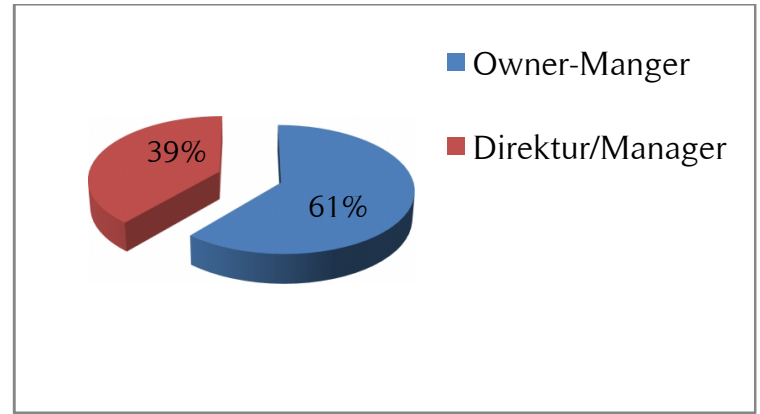

Gambar 1. Posisi/Jabatan Responden

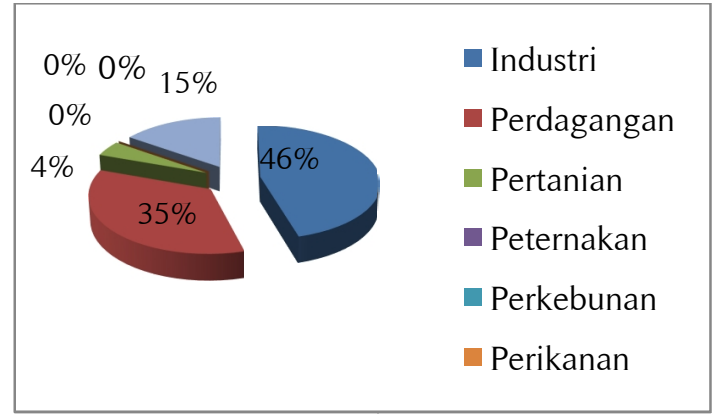

Gambar 2. Jenis Usaha Responden

Gambar 1 dan 2 menjelaskan posisi jabatan responden dan jenis usaha responden. Gambar 1 menunjukkan bahwa sebagian besar responden adalah manager-owner $(61 \%)$ dan sisanya adalah manajer atau pelaksana yakni sebesar 39\% dari total responden. Gambar 2 menunjukkan bahwa sebagian besar responden melakukan usaha industri dan perdagangan, yaitu sebesar $46 \%$ (21 responden) dan 35\% (16 responden). Hal ini sesuai dengan karakteristik Malang Raya berpotensi pada industri makanan dan minuman serta asesoris otomotif, dan perdagangan dengan dipicu oleh pertumbuhan industry pariwisata baik skala propinsi maupun nasional. Sektor usaha pertanian sebesar 4\% (2 responden), dan sektor jasa sebesar 15\% (7 responden).

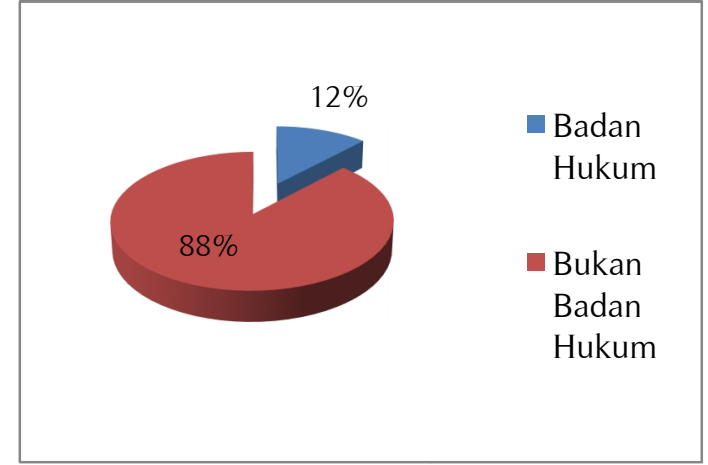

Gambar 3. Status Usaha Responden

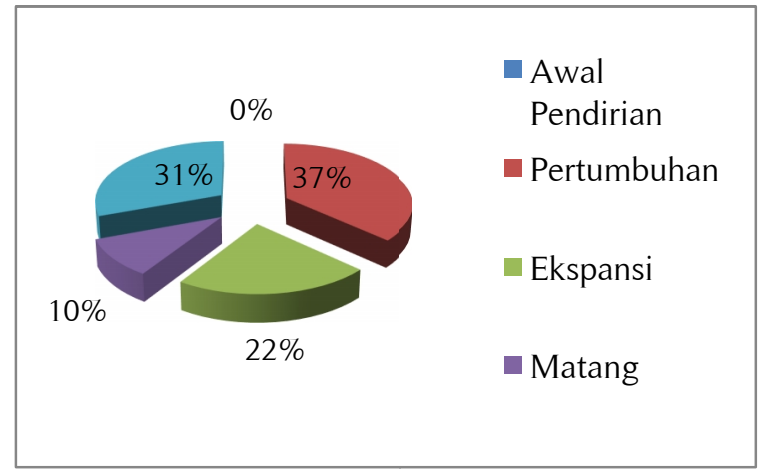

Gambar 4. Tahapan Siklus Bisnis Responden

Gambar 3 menjelaskan status usaha dari para responden, dimana sebagian besar masih belum berbadan hukum sebesar $88 \%$ (44 responden). Hal ini berkaitan bahwa sebagian besar responden adalah perusahaan perseorangan atau sebuah persekutuan $\mathrm{CV}$, dan hanya $12 \%$ (5 responen) yang telah mempunyai status badan hukum perseoraan terbatas (PT). Berkenaan dengan kategori tahapan usaha pada sebuah siklus bisnis pada gambar 4, sebagian besar responden berada pada tahapan pertumbuhan yakni 37\% (18 responden). Informasi tambahan pada kuisioner menjelaskan bahwa rata-rata industry makanan dan minuman serta jasa real estate sedang pada fase pertumbuhan. Sementara terdapat 22\% (11 responden) yang sedang pada tahapan ekspansi, seperti industi asesoris otomotif. Selanjutnya ada $10 \%$ (5 responden) berpersepsi bahwa usaha mereka sedang pada fase matang, dan 31\% (15 responden) merasa sedang mengalami masa penurunan.

Gambar 5 dan gambar 6 menjelaskan besaran perusahaan dari jumlah omset per bulan dan rata-rata aset berupa mesin dan peralatan UKM. Dimana mengacu pada UU Nomor 20 tahun 2008 tenatng Usaha Mikro, Kecil dan Menengah dapat diketahui bahwa yang menjadi responden pada 
penelitian ini adalah sebagian besar usaha menengah sebanyak 55\% (27 responden) dengan estimasi penjulan per bulan di atas Rp100.000.000,00 atau lebih dari Rp2.500.000.000 per tahun. Selanjutnya sebesar $23 \%$ dan $14 \%$ dari total responden masuk dalam ketegori usaha kecil, dengan omset antara Rp300.000.000 sampai dengan Rp2.500.000.000. Kemudian gamber 5 juga menunjukkan terdapat $8 \%$ (4 responden) yang masuk dalam kategori usaha mikro dengan omset per tahun kurang dari Rp300.000.000.

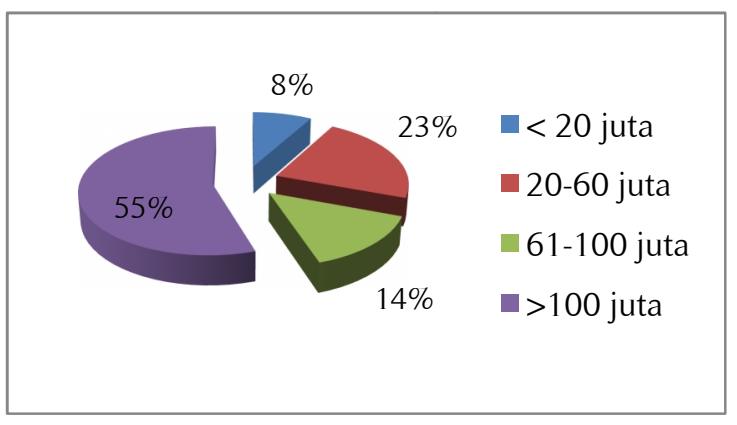

Gambar 5. Penjualan per Bulan

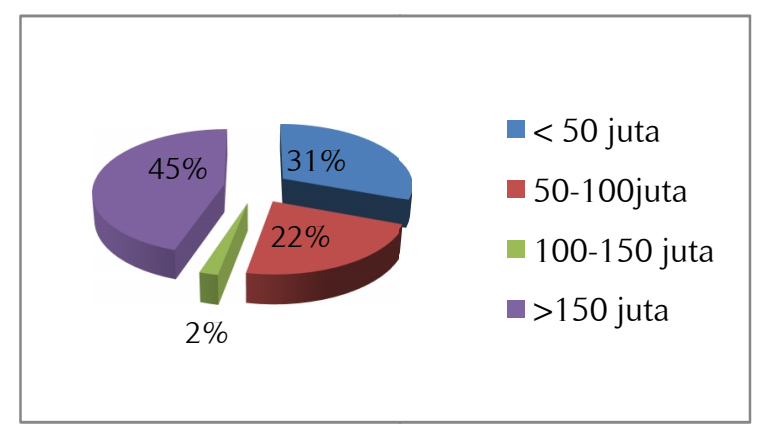

Gambar 6. Nilai Mesin dan Peralatan

\section{Tingkat Implementasi Good Corporate Goveranance Pada UKM}

Berikut merupakan statistik deskriptif digunakan sebagai analisis awal atas tingkat implementasi mekanisme good corporate governance di UKM responden penelitian.

Tabel 2. Statistik Deskriptif

Tingkat Implementasi Good Corporate Governance pada UKM

\begin{tabular}{|c|c|c|c|c|}
\hline Butir-Butir Pertanyaan & Mean & SD & Min & Max \\
\hline \multicolumn{5}{|l|}{ Pilar 1 Mengadopsi rerangka formal mekanisme corporate governance } \\
\hline Hak dan kewajiban pemegang saham/pemilik secara jelas ditentukan & 3,96 & 1,21 & 1 & 5 \\
\hline b. Delegasi wewenang diformalkan secara tertulis & 3,96 & 1,21 & 1 & 5 \\
\hline Jumlah rapat pimpinan dalam setahun & 1,69 & 1,06 & 1 & 4 \\
\hline Proses monitoring pemilik kepada pelaksana & 1,98 & 1,18 & 1 & 4 \\
\hline \multicolumn{5}{|l|}{ Pilar 2 Melakukan proses perencanaan suksesi pimpinan perusahaan } \\
\hline $\begin{array}{l}\text { a. Perencanaan suksesi merupakan perencanaan jangka panjang yang selaras } \\
\text { dengan visi/misi UKM }\end{array}$ & 3,98 & 0,80 & 2 & 5 \\
\hline $\begin{array}{l}\text { Perusahaan mempunyai metode pergantian pimpinan baik rencana utama } \\
\text { maupun rencana alternatif }\end{array}$ & 3,20 & 1,02 & 2 & 5 \\
\hline Bentuk perencanaan Exit Strategy bagi para pendiri & 2,33 & 0,83 & 1 & 3 \\
\hline \multicolumn{5}{|l|}{ Pilar 3 Menetapkan pola informasi yang tepat waktu, terbuka dan transparan } \\
\hline $\begin{array}{l}\text { a. Seluruh pemegang saham seharusnya mendapat perlakuan yang sama dan } \\
\text { perusahaan menetapkan cara/alat komunikasi yang efektif dengan para } \\
\text { pemegang saham }\end{array}$ & 4,22 & 0,42 & 4 & 5 \\
\hline $\begin{array}{l}\text { b. Mekanisme yang efektif (RUPS atau rapat lainnya) dilakukan untuk } \\
\text { menampung pandangan pemilik }\end{array}$ & 4,20 & 0,41 & 4 & 5 \\
\hline Jumlah laporan keuangan kepada pemilik dalam 1 tahun & 1,53 & 0,94 & 1 & 4 \\
\hline Kelengkapan Laporan keuangan & 1,84 & 1,18 & 1 & 4 \\
\hline \multicolumn{5}{|l|}{ Pilar 4 Kesungguhan upaya membentuk secara formal Dewan Komisaris/Direksi } \\
\hline $\begin{array}{l}\text { a. Perusahaan dengan ukuran lebih kecil dapat membentuk 'Penasehat' tanpa } \\
\text { kewenangan formal namun mempunyai keahlian khusus serta koneksi untuk } \\
\text { mendukung perkembangan bisnis. }\end{array}$ & 3,84 & 0,90 & 2 & 5 \\
\hline b. Dewan Komisaris dan Direksi seharusnya dibentuk melalui prosedur formal. & 4,06 & 0,59 & 3 & 5 \\
\hline $\begin{array}{l}\text { c. Perusahaan seharusnya memulai untuk mengajak pihak independen sebagai } \\
\text { anggota Dewan Komisaris atau Penasehat tetap }\end{array}$ & 3,22 & 0,80 & 2 & 4 \\
\hline $\begin{array}{l}\text { d. Komisaris ataupun anggota direksi baru harus mengikuti program pelatihan } \\
\text { sebagai komisaris atau direksi }\end{array}$ & 3,73 & 0,81 & 2 & 5 \\
\hline
\end{tabular}


Pilar 5 Mengembangkan mandat yang jelas kepada Dewan Komisaris/Penasehat untuk pengawasan kinerja

a. Dalam rangka memenuhi perannya, Dewan Komisaris harus mempunyai dukungan dan menerima informasi untuk menjalankan tugas utama

b. Penasehat atau komisaris indepeden melakukan pertemuan secara rutin untuk memonitor dan mengevaluasi kinerja manajemen

c. Penasehat atau Dewan Komisaris melakukan evaluasi atas kinerja secara berkala

d. Penasehat seharusnya tidak merangkap jabatan operasional dalam perusahaan. Formalisasi AD/ART Perusahaan Jumlah Dewan Komisaris atau Dewan Penasehat Jumlah Direksi atau Pimpinan Perusahaan Mekanisme Penentuan Remunerasi bagi Dewan Komisaris/Direksi atau Pimpinan Perusahaan

Pilar 6 Melakukan pembukuan yang diaudit oleh auditor eksternal

a. Perusahaan seharusnya melakukan praktik akuntansi yang kredibel dan menunjuk kantor akuntan independen dalam menyajikan laporan keuangan.

b. Perusahaan seharusnya mengevaluasi efektifitas audit eksternal dan menjaga independensi fungsi audit

$\begin{array}{llll}4,12 & 0,56 & 3 & 5 \\ 3,96 & 0,96 & 2 & 5 \\ & & & \\ 3,76 & 0,80 & 2 & 5 \\ & & & \\ 4,20 & 0,64 & 3 & 5 \\ 2,08 & 1,22 & 1 & 4 \\ 2,02 & 1,18 & 1 & 4 \\ 1,45 & 0,50 & 1 & 2 \\ 1,51 & 0,94 & 1 & 4\end{array}$

$\begin{array}{llll}3,86 & 0,89 & 2 & 5 \\ 3,96 & 0,84 & 2 & 5\end{array}$

Pilar 7 Menetapkan kerangka pengendalian internal dan melakukan reviu risiko secara berkala

a. Perusahaan seharusnya melakukan proses formal untuk mengidentifikasi risiko bisnis dan mengadopsi mekanisme pengendaliannya

b. Semakin besar ukuran perusahaan, sebaiknya mengadopsi komite pengawasan untuk memonitor keseluruhan lingkungan pengendalian perusahaan

c. Perusahaan perlu mempunyai fungsi audit internal Adanya code of conduct bagi seluruh anggota perusahaan Apakah ada pola penerapan sistem pengendalian internal

Pilar 8 Menganali kebutuhan pemangku kepentingan

a. Kebijakan perusahaan seharusnya mengatur hubungan perusahaan dengan para pemangku kepentingan

b. Dalam proses pengambilan keputusan, pemangku kepentingan berikut sangat penting dalam keberlanjutan perusahaan:

Pelanggan

Suppliers

Pegawai

Pemberi Modal

Pemberi Pinjaman/Bank

Pemerintah/Perpajakan

Asosiasi/Paguyuban

c. Sasaran terkait hubungan dengan pemangku kepentingan jelas dan indikator diukur dan dimonitor.

Apakah pernah melakukan studi kelayakan bisnis semisal analisis SWOT

Pilar 9 Formulasi kerangka yang menjelaskan hubungan keluarga dan bisnis

a. Aturan dalam keluarga sebaiknya menjelaskan visi keluarga serta kebijakan mengatur hubungan keluarga dengan bisnis

b. Kesepakatan tata kelola keluarga perlu ada untuk menfasilitasi komunikasi yang efektif serta koordinasi antara anggota keluarga dan perusahaan

Proporsi jumlah karyawan anggota keluarga

$\begin{array}{llll}4,10 & 0,31 & 4 & 5 \\ 4,00 & 0,87 & 2 & 5 \\ & & & \\ 3,88 & 0,33 & 3 & 4 \\ 1,88 & 0,60 & 1 & 3 \\ 1,69 & 0,98 & 1 & 4 \\ & & & \\ 3,90 & 0,71 & 2 & 5\end{array}$

Kesamaan penggajian antara keluarga dan non-keluarga

Sumber: Data diolah

\begin{tabular}{llll}
4,08 & 0,91 & 2 & 5 \\
3,98 & 0,85 & 2 & 5 \\
3,84 & 0,90 & 2 & 5 \\
3,86 & 0,76 & 2 & 5 \\
3,57 & 0,98 & 2 & 5 \\
3,31 & 1,06 & 2 & 5 \\
3,31 & 1,06 & 2 & 5 \\
4,00 & 0,00 & 4 & 4 \\
& & & \\
2,69 & 1,26 & 1 & 4 \\
& & & \\
3,65 & 1,28 & 1 & 5 \\
& & & \\
3,33 & 1,26 & 1 & 4 \\
& & & \\
3,69 & 0,92 & 1 & 4 \\
3,59 & 0,81 & 2 & 4 \\
\hline
\end{tabular}

a. Kebijakan dan Prosedur Corporate Governance

Dalam menjalankan sebuah mekanisme good corporate governance, perusahaan seharunya mengadopsi sebuah rerangka corporate governance secara formal yang mengatur peran organ utama perusahaan. Selain hal tersebut dalam menjalankan kebijakan dan prosedur tersebut, sebuah perusahaan skala UKM seharusnya melakukan proses perencanaan suksesi (penggantian 
pimpinan) dalam rangka memastikan keberlanjutan hidup dan bisnis perusahaan (business survival and continuity).

Untuk memastikan ada kebijakan dan prosedur corporate governance, para responden diminta untuk memberikan: (1) persetujuan atas tahapan dalam rangka mengadopsi rerangka tata kelola secara formal dan (2) pola pendelegasian wewenang tertentu perusahaan kepada manajemen. Selanjutnya sebuah pertanyaan tambahan digunakan untuk mengetahui bagaiama kedua tahapan tersebut dilaksanakan di perusahaan. Berikut tabel 2 menjelaskan persetujuan dan persepsi atas kebijakan dan prosedur corporate governance.

Tabel 3. Persepsi Responden terhadap Kebijakan dan Prosedur Corporate Governance

\begin{tabular}{llc}
\hline Pilar 1 Mengadopsi rerangka formal atas mekanisme governance & $\begin{array}{c}\text { Persetujuan } \\
(\%)\end{array}$ \\
\hline 1) & Hak dan kewajiban pemegang saham atau rekan secara jelas ditentukan & $79,2 \%$ \\
2) & Delegasi wewenang kepada manajemen dilakukan secara tertulis & $79,2 \%$ \\
\hline Pilar 2 Melakukan proses perencanaan suksesi & $79,6 \%$ \\
\hline 3) & $\begin{array}{l}\text { Perencanaan suksesi merupakan perencanaan jangka panjang yang harus selaras } \\
\text { dengan visi dan misi perusahaan }\end{array}$ & $64,1 \%$ \\
& $\begin{array}{l}\text { Perusahaan mempunyai metode pergantian pimpinan baik rencana utama maupun } \\
\text { rencana alternatif }\end{array}$ & \\
\hline
\end{tabular}

Sumber: Data diolah, 2014.

Berdasarkan tabel 3 tersebut, responden perusahaan UKM memberikan tingkat kepentingan yang besar pada pilar 1 tentang aspek rerangka formal atas mekanisme yang mengatur hak dan kewajiban para pemegang saham dan 'key bodies' secara jelas. Dalam praktek corporate governance, perusahaan UKM dengan beberapa status hukumnya perlu menetukan keputusan-keputusan mana saja yang membutuhkan 'persetujuan' dari pemegang saham/rekan, manajemen puncak atau level manajer operasional (semisal, dapat menentukan besaran Rupiah tertentu) secara formal tertulis. Pendelegasian wewenang juga dapat direviu secara periodik untuk memastikan bahwa kebijakan dan prosedur masih cocok dengan struktur, ruang lingkup dan kekomplekan seiring pertumbuhan perusahaan UKM tersebut.

Pada Pilar 2 tentang perencanaan suksesi, responden memberikan peringkat penting pada tahapan succecion plan $(79,6 \%)$ daripada cara pergantian pimpinan dilakukan $(64,1 \%)$. Hal ini sangat erat kaitannya dengan responden yang sebagian besar adalah pemilik dan sekaligus manajer (owner-manager) sebesar $61 \%$ dari seluruh responden (lihat gambar 1). Responden ini berkepentingan terhadap bagaimana keterlibatannya pada masa mendatang dalam operasional perusahaan, dengan cara mewariskan pada keluarga atau pada rekan bisnis atau bahkan mencari model exit strategy melalui penjualan pada pihak ketiga ataupun pasar modal. Metode pergantian pimpinan perusahaan bagi sebagian UKM tidak terlalu penting. Konsep dari tahap ini sebernarnya adalah untuk tetap menjaga penunjukan pimpinan dan key bodies dapat menjamin keseimbangan tersedianya pengalaman dan keahlian tertentu dalam UKM yang bersangkutan.

b. Transparansi dan Hubungan dengan Pemegang Saham

Dalam rangka mengetahui bagaimana transparansi diimplementasikan oleh UKM, responden diminta persetujuan dan persepsinya atas bagaimana mekanisme transparansi terhadap pemegang saham seharusnya dilakukan. Tabel 4 menunjukkan bahwa responden memberikan persetujuan yang tinggi (diatas $84 \%$ ) atas 2 butir pertanyaan tentang transparansi. Informasi yang umum diketahui oleh para pemegang saham, semisal posisi keuangan (neraca), kinerja, kepemilikan saham dan status dari tata kelola perusahaan. 
Tabel 4. Persepsi Responden terhadap Transparansi dan Hubungan dengan Pemegang Saham

\begin{tabular}{llc}
\hline $\begin{array}{l}\text { Pilar } 3 \text { Menetapkan penyampaian informasi dan komunikasi yang tepat waktu, terbuka } \\
\text { dan transparan kepada pemegang saham }\end{array}$ & $\begin{array}{c}\text { Persetujuan } \\
(\%)\end{array}$ \\
\hline 1) & $\begin{array}{l}\text { Seluruh pemegang saham seharusnya mendapat perlakuan yang sama dan perusahaan } \\
\text { menetapkan cara/alat komunikasi yang efektif dengan para pemegang saham }\end{array}$ & $84,5 \%$ \\
2) $\begin{array}{l}\text { Mekanisme yang efektif (RUPS atau rapat lainnya) harus dilakukan untuk } \\
\text { menampung pandangan pemegang saham }\end{array}$ & $84,1 \%$ \\
\hline
\end{tabular}

Sumber: Data diolah, 2014.

c. Dewan Komisaris dan Direksi

Pada sebuah Perseroan Terbatas, Dewan Komisaris dan Direksi berperan sangat penting dalam mekanisme corporate governance. Struktur ini dibentuk sebagai alat monitoring para pemegang saham kepada manajemen perusahaan. Penelitian ini menanyakan persepsi responden, perusahaan UKM, terhadap adanya struktur Dewan Komisaris dan Direksi. Tampak paada tabel 5 , bahwa sebagian besar responden menyatakan persetujuan $(81,2 \%)$ atas pembentukan Dewan Komisaris dan Direksi. Perusahaan dengan skala yang lebih kecil memberikan tingkat persetujuan sebesar $76,7 \%$ untuk membentuk 'Penasehat' tanpa kewenangan formal dengan keahlian khusus serta koneksi untuk mendukung perkembangan bisnis. Selanjutnya, program induksi bagi komisaris maupun anggota direksi baru diperlukan untuk membentuk adanya Dewan Komisaris dan Direksi yang kompeten.

Tabel 5. Persepsi Responden terhadap Dewan Komisaris dan Direksi

\begin{tabular}{|c|c|}
\hline Pilar 4 Kesungguhan upaya membentuk secara formal Dewan Komisaris dan Direksi & $\begin{array}{l}\text { Persetujuan } \\
\quad(\%)\end{array}$ \\
\hline $\begin{array}{l}\text { 1) Perusahaan dengan ukuran lebih kecil dapat membentuk 'Penasehat' tanpa } \\
\text { kewenangan formal namun mempunyai keahlian khusus serta koneksi untuk } \\
\text { mendukung perkembangan bisnis. }\end{array}$ & $76,7 \%$ \\
\hline 2) Dewan Komisaris dan Direksi seharusnya dibentuk melalui prosedur formal. & $81,2 \%$ \\
\hline $\begin{array}{l}\text { 3) Perusahaan seharusnya memulai untuk mengajak pihak independen sebagai anggota } \\
\text { Dewan Komisaris atau Penasehat }\end{array}$ & $64,5 \%$ \\
\hline $\begin{array}{l}\text { 4) Komisaris ataupun anggota direksi baru harus mengikuti program pelatihan sebagai } \\
\text { komisaris atau direksi }\end{array}$ & $74,7 \%$ \\
\hline \multicolumn{2}{|l|}{$\begin{array}{l}\text { Pilar } 5 \text { Mengembangkan mandat yang jelas kepada Dewan Komisaris untuk tugas } \\
\text { pengawasan kinerja operasi dan mengevaluasi perbaikan strategi bisnis }\end{array}$} \\
\hline $\begin{array}{l}\text { 1) Dalam rangka memenuhi perannya, Dewan Komisaris harus mempunyai dukungan } \\
\text { dan menerima informasi untuk menjalankan tugas utama }\end{array}$ & $82,4 \%$ \\
\hline $\begin{array}{l}\text { 2) Penasehat atau komisaris indepeden melakukan pertemuan secara rutin untuk } \\
\text { memonitor dan mengevaluasi kinerja manajemen }\end{array}$ & 79 , \\
\hline 3) Penasehat atau Dewan Komisaris melakukan evaluasi atas kinerja secara berkala & 75 \\
\hline 4) Penasehat seharusnya tidak merangkap jabatan operasional dalam perusahaan. & $84,1 \%$ \\
\hline
\end{tabular}
Sumber: Data diolah, 2014.

d. Lingkungan Pengendalian

Dalam mengembangkan sebuah lingkungan pengendalian yang baik, best practice internasional (seperti dalam Dubai SME, 2011) merekomendasikan pelaksanaan pembukuan yang kredibel dan efektifnya mekanisme pengendalian internal. Berkenaan dengan pilar 6 dan pilar 7 atas implementasi good corporate governance, tabel 6 menunjukkan prioritas pelaku UKM atas kedua pilar tersebut. Pada pilar 6, responden setuju atas terlaksananya praktik akuntansi yang kredibel dan keterlibatan kantor akuntan independen dalam proses penyajian laporan keuangan. Hal ini dibuktikan dengan adanya $77,1 \%$ persetujuan atas butir pertanyaan terkait. Namun 
demikian, para pelaku UKM cenderung memberikan prioritas atas evaluasi efektifitas auditor eksternal (79,2\%). Beberapa responden menjelaskan bahwa keterlibatan kantor akuntan publik (KAP) seringkali bersifat arahan dari Bank dimana UKM akan memperoleh pinjaman. Hal ini mungkin disebabkan pihak KAP cenderung formal dalam mengumpulkan data keuangan, dan mungkin dirasa kurang memberikan value kepada UKM yang diaudit.

Tabel 6. Persepsi Responden terhadap Lingkunan Pengendalian

\begin{tabular}{llc}
\hline \multicolumn{2}{l}{ Pilar 6 Melakukan pembukuan yang diaudit oleh auditor eksternal } & $\begin{array}{c}\text { Persetujuan } \\
(\%)\end{array}$ \\
\hline 1) & $\begin{array}{l}\text { Perusahaan seharusnya melakukan praktik akuntansi yang kredibel dan menunjuk } \\
\text { kantor akuntan independen dalam menyajikan laporan keuangan. }\end{array}$ & $77,1 \%$ \\
2) & $\begin{array}{l}\text { Perusahaan seharusnya mengevaluasi efektifitas audit eksternal dan menjaga } \\
\text { independensi fungsi audit }\end{array}$ & $79,2 \%$ \\
\hline Pilar 7 Menetapkan kerangka pengendalian internal dan melakukan reviu risiko berkala & \\
\hline 1) & $\begin{array}{l}\text { Perusahaan seharusnya melakukan proses formal untuk mengidentifikasi risiko bisnis } \\
\text { dan mengadopsi mekanisme pengendaliannya }\end{array}$ & $82,0 \%$ \\
2) & $\begin{array}{l}\text { Semakin besar ukuran perusahaan, sebaiknya mengadopsi komite pengawasan untuk } \\
\text { memonitor keseluruhan lingkungan pengendalian perusahaan }\end{array}$ & $80,0 \%$ \\
3) Perusahaan perlu mempunyai fungsi audit internal & $77,6 \%$ \\
\hline
\end{tabular}

Sumber: Data diolah, 2014.

Berkenaan dengan kerangka pengendalian internal, tabel 6 juga menjelaskan preferensi responden terhadap sistem pengendalian internal (SPI), manajemen risiko, komite pengawasan serta adanya pengawas internal. Data responden menjelaskan bahwa prioritas melakukan identifikasi risiko bisnis merupakan hal yang sangat penting (82\%) bagi para responden. Terkait bahwasanya $37 \%$ responden dalam fase pertumbuhan, maka kekhawatiran para pengusaha atas business survival dan continuity sangat besar. Kemudian, dengan semakin tumbuh perusahaan kebutuhan atas komite pengawasan (semisal adanya komite audit, komite lain dibawah Dewan Komisaris atau Direksi) menjadi semakin penting dengan skor sebesar 80,0\%. Selanjutnya, dalam implementasi sistem pengendalian internal, adanya fungsi audit internal juga diperlukan (skor $77,6 \%$ ).

e. Hubungan dengan Pemangku Kepentingan

International best practice mengklasifikasikan pemangku kepentingan perusahaan dalam kelompok pegawai, pemasok, kreditor, pemerintah, masyarakat dan lingkungan serta berbagai pihak yang berkaitan dengan perusahaan. Tabel 7 menunjukkan persepsi dari responden UKM terhadap pilar 8 hubungan dengan para pemangku kepentingan yang ada.

Responden menunjukkan persetujuan sebesar $78 \%$ atas adanya kebijakan yang mengatur hubungan dengan para pemangku kepentingan. Perusahaan sebaiknya memformulasikan kebijakan yang menjelaskan nilai dan tujuan perusahaan berkaitan kepuasan pelangan, keamanan produk, hubungan dengan pegawai, kesehatan dan keamanan kerja (health \& safety), kebijakan terhadap lingkungan serta masyarakat dimana perusahaan beroperasi. Lebih lanjut dengan memperhatikan faktor business survival and continuity, responden menempatkan pelanggan pada urutan terpenting. Hal ini diikuti oleh pemasok, pemodal, pegawai, kreditor dan terakhir pemerintah (perpajakan) serta paguyuban.

Para pelaku UKM juga mulai menyadari arti penting manajemen kinerja. Hal ini ditunjukkan dengan persepsi responden (80\%) untuk melakukan evaluasi atas indikator hubungan dengan pemanku kepentingan. 
Tabel 7. Persepsi Responden terhadap Hubungan dengan Pemangku Kepentingan

\begin{tabular}{lc}
\hline Pilar 8 Mengenali kebutuhan pemangku kepentingan & $\begin{array}{c}\text { Persetujuan } \\
(\%)\end{array}$ \\
\hline 1. Kebijakan perusahaan seharusnya mengatur hubungan perusahaan dengan para & $78,0 \%$ \\
pemangku kepentingan & \\
2. Dalam proses pengambilan keputusan, pemangku kepentingan berikut sangat penting & $81,6 \%$ \\
dalam keberlanjutan perusahaan: & $79,6 \%$ \\
a) Pelanggan & $76,7 \%$ \\
b) Suppliers & $77,1 \%$ \\
c) Pegawai & $71,4 \%$ \\
d) Pemberi Modal & $66,1 \%$ \\
e) Pemberi Pinjaman/Bank & $66,1 \%$ \\
f) Pemerintah/Perpajakan & $80,0 \%$ \\
g) Asosiasi/Paguyuban & \\
Sasaran terkait hubungan dengan pemangku kepentingan harus jelas dan indikator & \\
tersebut diukur dan dimonitor. &
\end{tabular}

Sumber: Data diolah, 2014.

\section{f. Family Governance}

Salah satu kharakteristik utama UKM di Indonesia adalah dikelola oleh kelompok sosial dengan pendidikan yang baik dan berasal dari rumah tanggan non-miskin (Tambunan, 2012). Sementara semakin perusahaan semakin besar, profil sosial ekonomi pengusaha semakin berasal dari keluarga yang makmur (wealthier family). Lebih lanjut, perusahaan kecil dan menengah lebih besar kecenderungan mempraktikkan sistem sumber daya manusia secara informal daripada usaha besar (Nguyen dan Bryant, 2004). Logika ini yang dapat digunakan bahwa perusahaan UKM dengan dominasi keluarga yang besar berpotensi menghadapi permasalahan dalam mengimplementasikan formalitas praktik SDM, serta mendorong adanya kewajaran dan kesetaraan.

Tabel 8 menyajikan persepsi responden pelaku UKM terhadap family governance pada perusahaan. Responden memberikan persetujuan yang tinggi atas perlunya sebuah aturan pada keluarga pemilik bisnis terhdap visi usaha dan hubungan keluarga dan bisnis $(73,1 \%)$. Hal ini dalam rangka mengurangi dampak permasalahan keluarga pada bisnis terutama pada fase generasi penerus (later generation). Kemudian, responden memberikan persetujuan sebesar $66,5 \%$ terhadap pola komunikasi dan koordinasi dalam kaitan kepentingan anggota keluarga dan perusahaan.

Tabel 8. Persepsi Responden terhadap Family Governance

Pilar 9 Formulasikan kerangka yang menjelaskan hubungan keluarga dengan bisnis Persetujuan

1) Aturan dalam keluarga sebaiknya menjelaskan visi keluarga serta kebijakan mengatur hubungan keluarga dengan bisnis

2) Kesepakatan tata kelola keluarga perlu ada untuk menfasilitasi komunikasi yang efektif serta koordinasi antara anggota keluarga dan perusahaan

$66,5 \%$

Sumber: Data diolah, 2014

\section{Diskusi dan Pembahasan}

Berdasarkan analisis awal atas statisitik deskriptif hasil survey menggunakan butir-butir pertanyaan pilar-pilar corporate governance UKM dengan skala likert dan pertanyaan tambahan untuk mendapatkan intensitas aktivitas governance diketahui bahwa secara umum tingkat persetujuan atas pilar-pilar governance pada UKM mulai dari $64,1 \%$ sampai dengan $84,5 \%$, yaitu setuju sampai dengan sangat setuju. 
Pada pilar 1 responden UKM menjelaskan bahwa rapat pimpinan dalam 1 tahun dilakukan rata-rata sebanyak 1 sampai dengan 2 kali. Pemisahan peran yang tidak terlalu ketat dijelaskan bahwa monitoring dan evaluasi peran manajemen dan pemilik dilakukan oleh orang yang sama. Hal ini logis pada saat sebuah perusahaan dilaksanakan oleh seorang manager-owner. Kharakteristik UKM yang dikelola oleh manager-owner juga menjadi faktor implementasi governance pada UKM (lihat Tambunan, 2008 serta Htay \& Salman, 2013).

Selanjutnya pilar 2, responden UKM rata-rata menjelaskan bahwa rencana jangka panjang suksesi manajemen antara memilih penerus dari anggota keluarga sendiri dan atau menunjuk tim manajemen professional. Penelitian menunjukkan bahwa belum ada responden yang memilih exit strategy dengan pengalihan pada pihak ketiga atau bahkan melakukan initial public offering (IPO) di bursa efek. Hal ini juga mejelaskan sangat sedikitnya UKM (dengan aset \pm Rp50miliar) yang mencatatkan sahamnya di Bursa Efek (BAPEPAM-LK, 2011). Berdasarkan penelitian BAPEPAM-LK (2011) ini, ada beberapa hal yang menjadi hambatan UKM menggunakan pilihan IPO sebagai salah satu exit strategy:

Regulasi UKM yang belum tersingkronisasi, semisal aturan pasar modal dan UU No.20 tahun 2008 tentang definisi UMKM.

Kesiapan fundamental dan mental UKM yang belum maksimal.

Struktur pembiayaan usaha yang didominasi oleh pasar uang (bank).

UKM rata-rata belum paham dengan pembiayaan jangka panjang seperti pasar modal.

Biaya listing di bursa yang cukup besar dibanding dana yang akan diperoleh.

Belum ada standarisasi/pedoman atas kriteria UKM dapat masuk di pasar modal.

Pada pilar 3 diketahui bahwa manajemen (perusahaan UKM) rata-rata menyampaikan informasi keuangan sebanyak 1 sampai dengan 2 kali setiap tahun kepada pemegang saham atau pemilik perusahaan. Selanjutnya, responden menjelaskan bahwa jenis laporan yang disampaikan rata-rata hanya berupa laporan laba-rugi, untuk menginformasikan kinerja periode berjalan, dan neraca sebagai laporan posisi keuangan. Dalam tingkatkan usaha yang tidak besar dan komplek, adanya laporan laba rugi dan laporan posisi keuangan sudah menjadi indikator terlaksananya asas transparasi dan akuntabilitas (DUBAI SME, 2011).

Pada UKM yang berbadan hukum PT, maka sebuah Rapat Umum Pemegang Saham (RUPS) merupakan forum pertemuan strategis bagi para pemegang saham, Dewan Komisaris dan Direksi. Perusahaan UKM yang telah berbadan hukum cukup mudah dengan mengacu pada UndangUndang No. 40 Tahun 2007 tentang Perseroaan Terbatas, atas mekanisme RUPS. Dengan logika yang sama, pada saat Perusahaan UKM berbentuk Perseorangan dan atau Commanditaire Vennootschap (CV) sebaiknya menyiapkan mekanisme internal rapat pimpinan agar dapat ikut serta berperan memberikan masukan serta berbagai hal semisal strategi bisnis baru. Adaptasi perlu guna mencipatakan mekanisme 'enggagement' yang efektif diantara rekan bisnis dengan manajemen perusahaan UKM yang bersangkutan.

Berkenaan dengan terpenuhinya pilar 4 dan pilar 5, responden diminta memilih status struktur organisasi berkenaan dengan peran Dewan Komisaris dan Direksi. Perusahaan UKM masih sedikit $(41,6 \%)$ yang memiliki sebuah Anggaran Dasar dan Anggaran Rumah Tangga (AD/ART). Hal ini dapat dikaitkan dengan gambar 6 yang menjelaskan $88 \%$ dari total responden belum berbadan hukum. Informasi dari responden menjelaskan bahwa sebagian besar perusahaan UKM memiliki 1 komisaris atau penasehat. Dalam UU No. 40 tahun 2007 dijelaskan bahwa Dewan Komisaris minimal 2 pada Perseroaan yang kegiatan usahanya berkaitan dengan menghimpun dan/atau mengelola dana masyarakat, Perseroan yang menerbitkan surat pengakuan utang kepada masyarakat atau Perseroan Terbuka.

Salah satu persepsi dari responden yang 'mengejutkan' adalah tingkat persetujuan yang rendah terhadap seperti hadirnya komisaris independen $(64,5 \%)$ yang mungkin dianggap sebagai pihak asing dalam organisasi. Hal ini dapat dipahami bahwa pada perusahaan UKM permasalahan 
keagenannya tidak dapat disamakan dengan yang terjadi pada perusahaan skala usaha besar (UB). Pada perusahaan besar pemisahan fungsi antara pemilik dengan manajemen (ownership-control separation) berpotensi memunculkan agency problem, sehingga sistem monitoring dalam struktur Dewan Komisaris diperlukan kehadiran orang independen. Namun tidak demikian dengan struktur organisasi UKM yang ownership-contro/sering dilakukan oleh orang yang sama.

Seiring tumbuhnya perusahaan UKM menjadi perusahaan yang semakin besar, semisal skala UB, adanya Dewan Komisaris yang efektif menjadi penting. Berdasarkan UU No 40 tahun 2007 tentang Perseroan Terbatas, Dewan Komisaris adalah organ perusahaan yang wajib dibentuk sejak awal. Namun demikian, pada saat usaha tersebut berbentuk Perseorangan maka hadirnya 'Penasehat' menjadi penting untuk formulasi strategi bisnis. Kemudian, perusahaan dengan status CV dapat meningkatkan status implementasi good corporate governance dengan mengefektifkan peran rekan diam (sekutu komanditer) dalam melakukan fungsi monitoring dan advising kepada sekutu komplementer (pengurus CV). Responden juga menjelaskan bahwa Direksi perusahaan UKM rata-rata terdiri dari 2 orang (29,0\%), biasanya Direktur Utama dan Direktur Operasional. Dalam istilah perusahaan UKM seringkali disebut dengan terminologi pimpinan dan manajer operasional. Seorang manager-owner biasanya mempunyai seseorang yang dipercaya untuk membantu tugas operasional sehari-hari dalam menjalankan bisnis perusahaan mulai dari fungsi produksi, marketing, keuangan dan SDM.

Data survey menjelaskan pelaksanaan pilar 7 tentang pengendalian internal, banyak dari pelaku UKM yang tidak mempunyai aturan perilaku (code of conduct) dan tidak mempunyai fungsi audit internal. Sistem pengendalian internal yang efektif dapat didorong dengan upaya mengembangkan lingkungan pengendalian, semisal mulai dari struktur organisasi yang fit sampai dengan penegakan integritas dan etika organisasi. Penelitian ini melaporkan bahwa responden mempunyai code of conduct yang bersifat informal dari pimpinan perusahaan (skor 37,6\%). Kemudian, hanya sebagian kecil mempunyai fungsi audit internal dan biasanya dilaksanakan oleh bagian keuangan (skor 33,9\%). Beberapa responden memberikan komentar umum bahwa proses bisnis masih sederhana dan proses pemantauan sampai pengendalian masih dapat dilakukan melalui pengendalian phisik, semisal oleh pimpinan atau manajer keuangan perusahaan sendiri.

Pada aspek lingkungan pengendalian, tampak dari data bahwa semakin besar perusahaan semakin diperlukan mekanisme lingkungan pengendalian formal. Perusahaan UKM dapat menyesuaikan komponen-komponen lingkungan pengendalian sesuai dengan kebutuhan, dengan tetap memperhatikan output berupa intergritas laporan keuangan perusahaan. Hal ini dalam rangka memastikan kelayakan kredit dan investasi perusahaan.

Pada pilar 8, evaluasi tambahan dalam instrumen penelitian menunjukkan bahwa setengah lebih dari UKM responden (53,9\%) pernah melakukan studi kelayakan (feasibility study) terutama aspek bisnis dan keuangan. Hal ini mengimplikasikan bahwa UKM mulai memahami positioning pada lingkungan bisnis mereka berada. Terakhir, pada pilar 9 responden UKM menyatakan bahwa $25 \%$ sampai dengan $49 \%$ karyawan berasal dari anggota keluarga. Hal ini menjelaskan bahwa UKM tidak lagi tergantung pada anggota keluarga pada aspek SDMnya. Para UKM tersebut juga telah memberikan standar gaji yang sama baik pegawai dari anggota keluarga atau bukan anggota keluarga. Namun demikian, memang ada fasilitas tambahan yang diberikan kepada anggota keluarga atas sepengatahuan pimpinan perusahaan. Hal ini memang tidak dapat dihindari bahwa inisiatif bisnis seringkali berkaitan upaya menciptakan suasana harmoni keluarga, semisal adanya fleksibiltas jam kerja, kompromi tanggungjawab kerja, serta adanya bentuk bantuan dan kemudahan lainnya.

\section{Kesimpulan dan Saran}

Dari hasil penelitian dan pembahasan yang telah diuraikan, survei dalam penelitian ini menemukan adanya 2 (dua) pola kecenderungan UKM dalam implementasi good corporate governance pada perusahaan. Pertama, Perusahaan Mikro (dengan penjulan $<$ Rp300.000.000/tahun) cenderung lebih 
memperhatikan business survival daripada melakukan implementasi mekanisme governance. Kedua, semakin besar ukuran perusahaan (kecil dan menengah) semakin besar kecenderungan melakukan implementasi governance. Pola kedua didukung adanya implementasi praktik manjerial secara formal dalam perusahaan.

Penelitian ini menggunakan usulan pilar-pilar good corporate governance yang sekiranya dapat diimplementasikan oleh UKM di Indonesia, diantaranya: 1) Kebijakan dan Prosedur Corporate Governance, 2) Transparansi dan Hubungan dengan Pemegang Saham, 3) Dewan Komisari dan Direksi, 4) Lingkungan Pengendalian, 5) Hubungan dengan Pemangku Kepentingan, dan 6) Family Governance. Secara umum, pedoman GCG (KNKG, 2006) dapat diimplementasikan oleh UKM, dengan beberapa modifikasi beberapa aspek. Modifikasi yang diperlukan diantaranya: pertama, adanya perbedaan status badan hukum UKM semisal perorangan dan CV. Hal ini disebabkan pedoman yang ada seringkali mengacu pada jenis Perseroan Terbatas (PT) dengan struktur two-tier board system yang sudah baku menurut UU 40/2007 tentang Perseroaan Terbatas.. Kedua, dengan banyaknya UKM Malang Raya dengan status perseorangan atau CV maka upaya memberdayakan 'penasehat' dan sekutu komanditer perlu dikembangkan dalam mendukung business survival and sustainability. Ketiga, pola family governance yang baik perlu dikembangkan dalam rangka mendukung pilar kewajaran dan kepatutan (fairness) dalam upaya mengoptimalkan potensi SDM perusahaan.

Penelitian ini merupakan penelitian eksplorasi atas bagaimana implementasi mekanisme good corporate governance pada UKM. Penelitian ini mempunyai potensi kelemahan karena terbatasnya jumlah sampel yang digunakan, sehingga masih lemah dalam hal generalisasinya. Penelitian lebih lanjut diperlukan dalam rangka mendapatkan masukan dari para pelaku UKM, terutama skala kecil dan menengah dengan jumlah sampel yang lebih representatif. Hal ini berkenaan dengan data survei awal ini bahwa perusahaan skala kecil dan menengah 'awareness' mulai meningkat dalam penerapan mekanisme governance. Selanjutnya in-dept interview diperlukan dalam rangka menggali lebih dalam jenis-jenis agency problem yang ada, sehingga dapat menentukan pengaturan-pengaturan yang tepat atas struktur dan proses governance pada UKM. Selain tersebut, pengujian hipotesis dengan melakukan survei perbandingan implementasi GCG pada UKM dan Usaha Besar juga perlu untuk memperoleh insight atas seksi/pilar apa yang secara statistic signifikan berbeda. Akhirnya, aspek-aspek tertentu dapat dipastikan bahwa tidak ada 'one size to fit all' dalam kaitannya dengan implementasi governance. Implikasi untuk regulator (semisal KNKG) untuk segera menerbitkan panduan khusus atas penerapan governance pada sektor UKM tersebut.

\section{Ucapan Terima Kasih}

Penulis menyampaikan terima kasih kepada DIKTI Kementerian Pendidikan dan Kebudayaan Republik Indonesia atas dukungan pendanaan penelitian melalui Politeknik Negeri Malang 2015. Terima kasih juga disampaikan atas komentar dan saran dari penelaah internal dan eksternal selama periode penelitian. Jika diperlukan, kuisioner penelitian dapat diperoleh dengan kontak langsung kepada Penulis.

\section{Daftar Pustaka}

Abor, J., \& Adjasi, C. K. (2007). Corporate governance and the small and medium enterprises sector: theory and implications. Corporate governance, 7(2), 111-122.

Abor, J., \& Biekpe, N. (2007a). Corporate governance, ownership structure and performance of SMEs in Ghana: implications for financing opportunities. Corporate governance, 7(3), 288300.

Achmad, T. (2007). Corporate governance of family firms and voluntary disclosure: the case of Indonesian manufacturing firms. Unpublished Phd, University of Western Australia, Perth. 
Adams, M., Armstrong, A., Clarke, A., Clarke, T., Eddie, I., Heenetigala, K., et al. (2011). Developing a Responsive Regulatory System for Australia's Small Corporations. Melbourne: Governance Research Program Victoria University.

ADB. (1999). Asian Development Bank Report 1999. Manila.

ADB. (2000). Corporate governance and finance in east Asia: a study of Indonesia, Republic of Korea, Malaysia, Philippine and Thailand. Manila: ADB.

ADB. (2000a). A consolidated report on corporate governance and financing in east Asia: executive summary. Paper presented at the OECD Second Asian Roundtable on Corporate Governance.

Albrecht, W \& Richardson, F 1990, 'Income smoothing by economy sector', Journal of Business Finance \& Accounting, vol. 17, no. 5, pp. 713-30.

BAPEPAM-LK. (2011). Potensi Perusahaan UKM untuk Go Publik. Jakarta: Departemen Keuangan Republik Indonesia.

Beasley, M. S. (1996). An empirical analysis of the rotation between the board of director composition and financial statement fraud. Accounting Review, 71(4), 443-465.

Berle, A. A., \& Means, G. C. (1932). The modern corporation and private property. New York: The MacMillan Company.

Cadbury, S. A. (1992). Report of the committee on the financial aspects of corporate governance. London.

Clarke, A. D. (2007). Corporate governance and SMEs: The forgotten stakeholders? Australian Business Law Review, 35(1), 7-17.

Creswell, J. W. (2009). Research design: qualitative, quantitative, and mixed methods approaches (3rd ed.): Sage Publication, Inc.

Denis, D. K. (2001). Twenty-five years of corporate governance research ... and counting. Review of Financial Economics, 10(3), 191-212.

Dharwadkar, R., George, G., \& Brandes, P. (2000). Privatization in emerging economies: An agency theory perspective. Academy of Management Review, 650-669.

DUBAI SME. 2011. The Code of Corporate Goverance for Small and Medium Enterprises.

Dube, I., Dube, D., \& Mishra, P. (2011). Corporate Governance Norm for SME. Journal of Public Administration and Governance, 1(2), Pages 77-123.

DuPlessis, J. J., James, M., \& Mirko, B. (2005). Principles of contemporary corporate governance. Melbourne: Cambridge University Press.

Eisenhardt, K. M. (1989). Agency theory: an assessment and review. Academy of Management Review, 14(1), 57-74.

Enriques, L., \& Volpin, P. (2007). Corporate governance reforms in continental europe. Journal of Economic Perspectives, 21(1), 117-140.

Farrar, J. (2008). Corporate governance: theories, principles, and practice (3rd ed.). Melbourne: Oxford University Press.

Firth, M., Fung, P. M. Y., \& Rui, O. M. (2007). Ownership, two-tier board structure, and the informativeness of earnings-Evidence from China. Journal of Accounting and Public Policy, 26(4), 463-496. 
Hong Kong Institute of Directors (2009). Guideline on Corporate Goverance for SMEs in Hong Kong, $2^{\text {nd }}$ Edition.

Hopt, K. J. (1998). The german two-tier board: experience, theories and reforms. SSRN eLibrary.

Htay, S. N. N., \& Salman, S. A. (2013). Corporate governance: A case study of SMEs in Malaysia. Middle-East Journal of Scientific Research, 18(2), 243-252.

Indonesian Stock Exchange (IDX), (2014). IDX Factbook 2014. IDX, Jakarta.

Iu, J., \& Batten, J. (2001). The implementation of OECD corporate governance principles in postcrisis Asia. Journal of Corporate Citizenship, 4, 47-62.

Jensen, M. C., \& Meckling, W. H. (1976). Theory of the firm: managerial behavior, agency costs and ownership structure. Journal of Financial Economics, 3(4), 305-360.

Johnson, La Porta, R., Lopez-de-Silanes, F., \& Shleifer, A. (2000). Tunneling. American Economic Review, 22-27.

Kamal, M. (2008) The new Indonesian company law: Does it support good corporate governance? Sydney: Macquarie Law WP 2008-24.

Kaplan, S. N. (1997). Corporate governance and corporate performance: A comparison of Germany, Japan, and the US. Journal of Applied Corporate Finance, 9(4), 86-93.

Kemenkop\&UKM. (2012). Perkembangan Data Usaha Mikro, Kecil, Menengah (UMKM) dan Usaha $\operatorname{Besar}(U B)$. Jakarta.

KNKG. (2006). Pedoman Umum Good Corporate Governance Indonesia.

LaPorta, R., Lopez-de-Silanes, F., Shleifer, A., \& Vishny, R. W. (1998). Law and finance. [Article]. Journal of Political Economy, 106(6), 1113.

Lin, C. (1998). Success factors of small-and medium-sized enterprises in Taiwan: an analysis of cases. Journal of Small Business Management, 36(4), 43-56.

Machfoedz, M., Sumiyana, Sari, R. C., \& Anggraini, F. R. R. (2009). Tunnelling, overlaping owner, and investor protection: evidence from merger and acquisition in Asia. Paper presented at the Simposium Nasional Akuntansi 12 [Internasional].

Mahmood, S. (2008, July). Corporate governance and business ethics for SMEs in developing countries: Challenges and way forward. In International Society of Business, Economics, and Ethics World Congress (pp. 15-18).

Maskur, Ani (2012) Analisis Pelaksanaan Good Corporate Goverance pada Usaha Kecil dan Menengah Studi Kasus pada Mitra Binaan Unit PKBL PT TASPEN (Persero). Thesis S2 UI, tidak dipublikasikan.

OECD (2009) Corporate Governance of Non-Listed Companies in Emerging Markets.

Purwanto, GK., \& Mustamu, RH. (2013) Studi Deskriptif Penerapan Prinsip-Prinsip Good Corporate Governance pada Perusahaan Keluarga di Bidang Manufaktur Kayu. AGORA, 1(1)

Rezaee, Z \& Riley, R 2010, Financial statement fraud: prevention and detection, 2nd edn, John Wiley \& Sons, Inc.

Shanthy R., \& Elsa S. (2009) "Improving corporate governance of SMEs in emerging economies: a Malaysian experience", Journal of Enterprise Information Management, Vol. 22 Iss: 4, pp.468- 484 
Shleifer, A., \& Vishny, R. W. (1997). A survey of corporate governance. The Journal of Finance, 52(2), 737-783.

Siwangaza, L., Smit, Y., Bruver, J., \& Ukpera, W. I. (2014). The Status of Internal Controls in Fast Moving Small Medium and Micro Computer Goods Enterprises within the Cape Peninsula. Mediteranian Journal of Social Sciences, 5 (10), 163-174.

Tambunan, T. (2005). Promoting small and medium enterprises with a clustering approach: A policy experience from Indonesia. Journal of Small Business Management, 43(2), 138-154.

Tambunan, T. (2008). SME development, economic growth, and government intervention in a developing country: The Indonesian story. Journal of International Entrepreneurship, 6(4), 147-167.

Wibowo, A. (2008). The impact of organisational culture and international corporate governance on organisational performance in Indonesian companies. Unpublished Phd, Curtin University, Perth.

World Bank. (1999). World Bank report. New York: World Bank.

World Bank. (2002). World Bank Group Review of Small Business Activities. New York: World Bank.

World Bank. (2004). World Bank Group Review of Small Business Activities. New York: World Bank. 